\title{
Beyond identity: Membership norms and regional organization
}

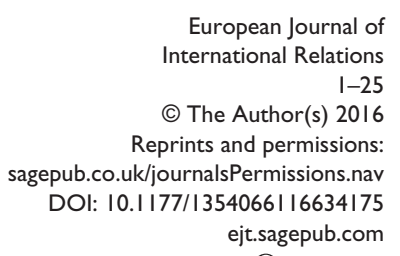

European Journal of $-25$ C) The Author(s) 2016
Reprints and permissions: @SAGE

\author{
Daniel C. Thomas \\ Leiden University, The Netherlands
}

\begin{abstract}
What is a region and how can we best understand a state's eligibility for membership in a regional political community? Scholars have sought to answer these questions in terms of geographic proximity and social-psychological identity, but neither concept can accommodate the contestation and change that characterize the social construction of regions. Instead, this article argues that the limits of regions are defined within regional organizations by member states' governments plus supranational actors deliberating over a common definition of the characteristics that members and potential members are expected to share. The concept of membership norms thus offers powerful insights into how regional communities define who is eligible for membership, how these definitions change over time and the incentives they create for those seeking to promote or block an applicant state. The evolution of the European Union's membership norms since the 1950s illustrates this argument.
\end{abstract}

\section{Keywords}

Europe, identity, integration, membership, norms, region

\section{Introduction}

How a regional community of states defines its limits and thus regulates which other states are eligible for membership has significant implications for the community's internal governance and external relations, as well as for political dynamics within states that wish to join. However, there is no agreement among politicians or scholars regarding the sources or evolution of these limits. For example, for some politicians, Europe is an

\footnotetext{
Corresponding author:

Daniel C. Thomas, Institute of Political Science, Leiden University, Leiden, The Netherlands.

Email: d.c.thomas@fsw.leidenuniv.nl
} 
entity whose geographic and cultural limits are stable and plainly seen, so eligibility for membership in the European Union (EU) is a simple question of regional identity (Giscard d'Estaing, 2000). In contrast, others note that the ultimate limits of the EU are fluid and controversial: 'Please don't ask me where the borders of Europe are, that's something we didn't want to put on the agenda', pleaded Finnish Foreign Minister Erkki Tuomioja while holding the EU's rotating presidency (Agence France-Presse, 2006). Similar debates are heard in other regions of the world. So, how can we best understand a state's eligibility for membership in a political community that is regional in scope and supranational in scale?

Although we cannot rely on 'geographical eyeballing or legalistic inspection' to answer such intensely political questions (Cederman, 2001: 2), the 'identity' concept commonly found in studies of regional integration is a weak substitute. Instead, the concept of membership norms offers clearer and more powerful insights into how supranational communities define what their members have in common and who is eligible to join, how these definitions change, and how they shape policy choices. Following this introduction, the article questions scholarship that interprets the social construction of regions in terms of identity. It then elaborates an alternative approach focused on the role of membership norms in discursive processes of regional community building. Finally, the article demonstrates the analytical advantages of this approach by tracing the emergence, contestation and evolution of European membership norms since the early 1950s. It thus challenges conventional understandings of what it means for a state to belong to a region.

\section{The construction of regions}

The definition of region in International Relations has often centred on the geographic proximity of states (Mansfield and Milner, 1997; Nye, 1971; Pevehouse, 2000). However, conceiving of regional geography as if it were defined by physical terrain does not provide a satisfactory explanation of a state's eligibility to join a regional organization. For example, neither the European Community's freezing of its association agreement with Greece (an explicit precursor to accession) after that country's military coup in 1967 nor the Association of Southeast Asian Nations' (ASEAN's) refusal to offer a membership prospect to Timor Leste over the last decade can be explained by the two states' locations. Sometimes, it is not even clear what physical geography is implied by the name of a particular region. As a former Secretary-General of ASEAN noted, 'The 1967 ASEAN Declaration states that "the Association is open for participation to all States in the SouthEast Asian Region subscribing to the aforementioned aims, principles and purposes." This raises the question: what precisely is Southeast Asia?' (Severino, 2006: 41).

In order to answer this and similar questions posed about other regions, one must first recognize that 'space is not given in nature. It is a social construct that people, somehow, invent' (Ruggie, 1999: 235). Or, as Edward Said (1978) argued, geography is meaningful and politically consequential principally through the ways in which it is imagined. As such, the border of a region 'is not a geographic fact that has sociological consequences, but a sociological fact that takes geographic form' (Hemmer and Katzenstein, 2002: 587). 
One way that political scientists address these issues is through the concept of identity, typically defined as 'relatively stable, role-specific understandings and expectations about the self' (Wendt, 1992: 397). Much of this literature focuses on individuals' sense of belonging to a region and sharing the characteristics of other individuals in the region. For example, much of the scholarship on European identity and socialization (Checkel, 2005; Checkel and Katzenstein, 2009; Herrmann et al, 2004; Risse, 2010) focuses on whether, how much and under what conditions individuals feel themselves to be European, instead of or in addition to whatever other identities they may feel.

Studying regional identity in this manner, with the same methods used to study ethnic or religious identity, is useful for understanding outcomes that aggregate individual preferences, such as trends in public opinion on a new treaty or a controversial applicant state. However, it is ill-suited to understanding the dynamics that define criteria for membership in a regional community or determine responses to applications from nonmembers. This is due partly to the misfit between individual and intergovernmental levels of analysis and partly to the tendency to reduce regional identity to self-reported identification without theorizing the meaning of this regional identity for respondents or how it changes over time.

Other scholars (Acharya, 2011; Kupchan, 2010) define regions first and foremost as groups of states that share a communal or cultural identity. In particular, some conceive of regions as cultural and political spaces whose identities evolve as actors attribute certain characteristics to an 'other' in order to provide meaning and coherence to their 'self'. For example, Iver B. Neumann (1999) and Bahar Rumelili (2004) have mapped changes in the meaning of Europe over time, tracing how it was constituted in opposition to various salient 'others', most notably Russia and Turkey, over decades and even centuries. Their logic is unassailable: no group of states can claim that certain characteristics distinguish its members without referring implicitly or explicitly to other states that lack the same characteristics, either entirely or in sufficient measure. However, this macro-historical constructivist approach is insufficiently flexible to explain relatively sudden but consequential changes in how a regional community responds to the membership aspirations of neighbouring states.

Instead of the interactionist approach, Frank Schimmelfennig (2001) suggests that the 'collective identity' of a region is composed of the values of its political leaders, the norms that they share and the regional organization's formal rules on accession. He thus explains the EU's eastern enlargement as a result of 'rhetorical action': when the states of Central and Eastern Europe framed their applications in terms of the EU's multidimensional identification with liberal democracy, EU member states accepted the applicants' quest for full membership despite its high cost. However, Schimmelfennig's work does not associate distinctive causal mechanisms with the three components of regional identity and thus cannot separate their respective contributions to the outcome in question. Furthermore, as a result of its limited historical scope, his study treats the content of EU values/norms/rules as fixed ('European' = liberal democracy) instead of recognizing and exploring how they vary over time. These shortcomings limit its explanatory power in the case of Europe and its generalizability to other cases. 
In sum, notwithstanding differences in how scholars define and operationalize regional identity, the concept is too blunt and too static to explain variations over space and time in decision-making by regional communities.

\section{Regional organizations and membership norms}

Instead of identity, a focus on regional organizations and their membership norms offers greater insight into how regional communities of states assess outsiders' eligibility to join the club. After all, the imagination or social construction of a geographic region occurs in large part through the development and activity of an international organization governing relationships within and beyond the region. Although best known for their technical activities, such as interest coordination and arbitration, these organizations also define, communicate and enforce distinctions between members and non-members (Abbott and Snidal, 1998). This starts with collective and sometimes competitive deliberations on the limits of the regional political community and how the community and its members are distinguished from others. In short, it starts with the creation and contestation of regional membership norms.

\section{Defining membership norms}

A regional membership norm is the definition prevailing within a regional community of the characteristics that distinguish or should distinguish its members from other states in the international system. They define what makes a state eligible or ineligible to join the international organization representing the community in question. They are composed of references to what 'we' have in common and especially to distinctions between 'us' and 'them' that dominate the discourse of senior representatives of the region's member states and senior officials from the region's international organization as they speak publicly and especially as they deliberate behind closed doors.

Membership norms are distinct logically and often empirically from individual beliefs, governmental preferences and formal membership rules such as those found in intergovernmental treaties. For example, membership norms may reflect the beliefs of a regional community's political leaders and/or they may be embedded in the community's formal documents, but not necessarily. Political elites may believe or want one thing but commit themselves publicly to something altogether different when operating as part of a group. Similarly, the language that diplomats adopt for treaties or other foundational documents may be chosen to serve various purposes and, in any case, is often not updated to reflect the evolving expectations of the community's members, which are subject to change and reformulation independent of formal texts.

Once established within a regional organization, membership norms determine the legitimacy of various membership scenarios and thus create incentives for community actors to accept certain states for membership and reject others, regardless of their preferences. This does not mean that norms alone determine a regional community's collective decisions on which states are granted (or allowed to retain) membership and which are not; other factors matter as well. Moreover, the impact that membership norms have on various actors (whether they are empowered or disempowered) depends on the fit 
between the prevailing norms and the actors' policy preferences. However, if current members value their standing within the community and prospective members value accession, then the norms defining how the eligibility of applicant states should be judged will be a significant determinant of their behaviour. The ability to deploy membership norms in political battles over the purposes and extent of a community of states is thus 'a very important category of power' (Hurrell, 2005: 40).

\section{The sources and evolution of membership norms}

As constructivists have long argued, international norms 'do not appear out of thin air; they are actively built by agents having strong notions about appropriate or desirable behavior in their community' (Finnemore and Sikkink, 1998: 896). The content and meaning of regional membership norms are thus subject to political contestation, from their initial creation to their transformation over time (Payne, 2001; Wiener, 2004). This contestation involves a process of 'strategic social construction' whereby actors compete to shape the intersubjective understandings that inform decision-making within the political community (Finnemore and Sikkink, 1998: 910-911).

When politicians and diplomats gather to discuss the creation of a new regional organization or community of states, they inevitably discuss its membership norms. These discussions may start with references to physical geography but they are also likely to be shaped by the material interests, domestic structures and cultural values of the initiating states, the challenges their governments face internally or externally, and the norms of other international organizations with overlapping membership. However, whatever consensus is achieved at this stage, membership norms remain subject to challenge and change over time, including relatively short periods of time.

Member states' governments, parliamentarians, supranational officials and civil society actors who question the norms' moral validity and/or see the norms as an obstacle to their preferences regarding regional governance or community enlargement may seek to change the interpretation or salience of existing membership criteria or even to introduce new criteria. The success of such challenges will largely depend upon the depth and breadth of member states' commitment to the existing norm and to the fit between proposed alternatives and other norms pre-existing within and around the community. For example, alternative membership norms that fit the constitutional norms of member states or the norms of other international organizations to which the member states also belong are more likely to be adopted than those that contradict member states' constitutions or lack international resonance.

However, contestation does not necessarily lead to evolutionary change. For example, if policymakers use the community's membership norms to justify a decision on whether or not to accept a particular applicant state and that decision is generally popular, the norm itself is likely to become stronger and more resistant to change. The resulting pattern of change is likely to resemble a punctuated equilibrium whereby norms persist for a while only to be overturned or transformed by forces that are themselves difficult to foresee (Krasner, 1988). At the extreme, a regional organization's membership norms may cease to exist altogether if the contestation is so severe or persistent that it impedes any collective redefinition of the criteria for membership. In this situation, there will be 
no normative constraints on member states' pursuit of national preferences in deliberations over changes in membership.

\section{Empirical analysis of membership norms}

To identify the membership norms of a regional community and trace their evolution over time requires extensive evidence of the language that community actors use in their internal deliberations and public pronouncements. Potential sources for this evidence include briefings and background papers prepared at the national or supranational level before community deliberations, transcripts or minutes from the meetings themselves, and follow-up reports prepared for distribution to national ministries and supranational bureaucracies. Where such documents are classified or otherwise inaccessible, interviews with former participants, memoirs, public declarations and press reports provide an alternative source. In order to distinguish membership norms from the self-serving rhetoric of political actors with distinct preferences regarding particular membership choices, it is also important to give less weight to statements made during deliberations on any particular applicant state.

The most effective technique to interpret this evidence is a genealogical approach combining discourse analysis and process tracing to uncover subjective understandings and intersubjective expectations as they emerge and evolve through social interaction (Klotz and Prakash, 2009). The purpose of the genealogical method is 'to illuminate the contingency of what we take for granted, to denaturalize what seems immutable, to destabilize seemingly natural categories as constructs and confines articulated by words and discourse and to open up new possibilities for the future' (Crowley, 2009: 341). It is therefore ideally suited to investigating how political actors conceive and re-conceive of eligibility for membership in a supranational regional community.

So, how do we know a membership norm when we see one? A regional membership norm exists when a regional organization's internal deliberations and public pronouncements express a (mostly) consistent definition of the characteristics that current and aspiring member states are expected to have. A change in membership norms is evident when such pronouncements express a new definition, including when community members choose not to contradict a novel definition by a relevant actor and then adjust their discourse on membership eligibility to suit the new definition. However, exceptional discourse by a minority within the community does not invalidate a norm as long as it is criticized or at least not adopted by other community actors. Such evidence is especially powerful when the normative discourse contradicts the material interests or demonstrated policy preferences of the actors involved.

\section{Case study: The evolution of EU membership norms}

This part of the article demonstrates how the dynamic understanding of regional membership norms presented earlier improves our understanding of regional integration and community building over time. To that end, it draws on extensive evidence of EU membership norms in the language used by member states' officials and their representatives, European Commission officials, and members of the European Parliament, speaking 
publicly or behind closed doors in official deliberations regarding the characteristics that distinguish the EU's member states from others in the international system. Primary sources include travaux préparatoires and procès verbaux from meetings of the member states, the internal notes of member states and EU institutions, and diplomatic correspondence and position papers found in national archives and the historical archives of EU institutions. These archival sources are supplemented by interviews, memoirs, speeches and other statements by key decision-makers, as well as contemporary print and electronic media accounts of the events in question. Discussion of more recent periods, for which primary sources are very limited, are by necessity shorter and more dependent on secondary sources.

\section{A Europe of non-communist states, 1957-1961}

The landmark treaty establishing the European Economic Community (EEC) that the governments of Belgium, France, Germany, Italy, Luxembourg and the Netherlands signed in Rome on 25 March 1957 called 'upon the other peoples of Europe who share their ideal to join in their efforts'. The treaty's article on membership declared simply: 'Any European state may apply to become a member of the Community.' So, what was the 'ideal' upon which the Six had chosen to build their new community, and what additional states, if any, were they ready to welcome as members? To answer these questions and to reveal the forces determining this outcome, it is necessary to examine the debates and negotiations that shaped the Treaty of Rome.

In the immediate aftermath of Germany's defeat in 1945, the principal challenge facing Europe was how to reconstruct the continent's shattered infrastructure and revive economic growth. However, in the eyes of many democratic politicians and former members of the anti-Nazi resistance, it was equally important to ensure Europe's new and restored democracies against any revival of fascism. As they saw it, this required bolstering democratic constitutions at the national level with strong supranational institutions capable of preventing authoritarian backsliding, including a membership norm limited to democracies that respect human rights. Various non-governmental and parliamentary bodies mobilized in pursuit of this goal.

In early May 1948, a congress of the non-governmental European Movement proposed the creation of a Council of Europe, a common declaration on human rights and an independent court of human rights. This new body, the congress declared, 'should be open to all democratic European nations which undertake to respect fundamental human rights' (Boyd and Boyd, 1950: 48). The following month, the European Parliamentary Union prepared its own draft constitution for a federal United States of Europe, whose 'supreme goal is to realize and guarantee in its States the fundamental rights of man enunciated in the preamble of the United Nations Charter'. The same text also stipulated that 'The Constitution of each member state must foresee the existence of a Parliament of which at least one Chamber must be freely elected on the basis of universal suffrage' (De Menthon, 1948).

Following these proposals, the governments of Belgium, Denmark, France, Germany, Ireland, Italy, Luxembourg, the Netherlands, Norway, Sweden and the UK signed the official Statute establishing the Council of Europe on 5 May 1949. Member states of this 
new body would be represented in a Council of Ministers empowered to make decisions on the basis of unanimity while their parliaments would send delegates to a parliamentary assembly. However, membership was limited expressly to democratic states that respect human rights and the rule of law:

Every member-state of the Council of Europe recognizes and accepts the principle of the rule of law and the principle that everyone who comes under its legal and sovereign authority is entitled to the basic human freedoms, and to human rights.

The Council's commitment to these principles was strengthened the following year by agreement on a European Convention on Human Rights and Fundamental Freedoms, which stipulated the creation of a supranational European Court of Human Rights and a Human Rights Commission to interpret and enforce its rules. Although separate from the institutional evolution towards and beyond the Treaty of Rome, the Council of Europe established an important normative benchmark against which political entrepreneurs often judged the EEC and its successors in later years.

Many of Europe's democratic politicians in this period were more concerned about the challenge posed by the far left than the far right. Communist parties were particularly strong in France and Italy, where they had led resistance to fascism and occupation, and their strong ties to Moscow raised fears that the egalitarian ideals that they espoused would someday become a cover for efforts to overthrow democracy, the rule of law and market-based economics. The uncompromising behaviour of communist parties in Soviet-controlled Eastern Europe, the Berlin crisis of 1948 and the outbreak of the Korean War in 1950 made this scenario all too imaginable. For politicians focused on the challenge of communism, both internally and externally, the surest solution lay in policies that would boost the standard of living and deepen economic ties between the countries of Western Europe.

In May 1950, French Foreign Minister Robert Schuman declared his government's desire to create a High Authority to control all coal and steel production in France and Germany. This proposal, he said, was intended 'as a first step in the federation of Europe', and was to be 'open to all countries willing to take part' . [T] he general objective assigned to the High Authority', Jean Monnet wrote a few weeks later, 'can be summarized by the formula of raising the standard of living by increasing productivity' (Stirk and Weigall, 1999: 77). On 18 April 1951, the foreign ministers of Belgium, France, Germany, Italy, Luxembourg and the Netherlands signed the treaty establishing the European Coal and Steel Community (ECSC). From the first draft circulated by the French in June 1950 to the final text signed 10 months later in Paris, the treaty made no mention of democracy or human rights, neither as a principle of the ECSC nor as a requirement for membership (United States Government Printing Office, 1977: 727-739). Instead, the treaty declared that 'Any European state may apply to accede'.

However, even after the Treaty of Paris, the tension between integration initiatives focused on bolstering democracy and those focused on raising living standards remained unresolved for some time. When French Prime Minister René Pleven proposed the creation of a European Defence Community (EDC) to contain a rearmed Germany, Italian federalists convinced Premier Alcide de Gasperi to insist that the 
EDC and the just-launched ECSC be encompassed within a supranational European Political Community (EPC) (Pistone, 1993; Preda, 1992). Responsibility for drafting an EPC treaty was given to the members of the ECSC's parliamentary assembly, reconstituted for this purpose as an 'ad hoc assembly' under the presidency of Paul-Henri Spaak.

The assembly's draft treaty stated that the EPC's first mission would be 'to contribute towards the protection of human rights and fundamental freedoms in Member States'. It also incorporated the core provisions of the European Convention for the Protection of Human Rights and Fundamental Freedoms as 'an integral part of the present Statute' and authorized the EPC to 'intervene' when a member state fails to maintain constitutional order and democratic institutions within its territories. Most important, and in stark contrast to the Treaty of Paris, the draft EPC treaty indicated that 'Accession to the Community shall be open to the Member States of the Council of Europe and to any other European State which guarantees the protection of human rights and fundamental freedoms' and authorized the community to 'conclude treaties or agreements of association ... with such third States as guarantee the protection of the human rights and fundamental freedoms' (Constitutional Committee, 1953a; see also Constitutional Committee, 1953b). The EPC treaty would thus have excluded from the emerging European community all states that did not respect democracy and human rights.

However, the lack of support among participating states for such a membership norm was confirmed in 1954, after the French Parliament blocked the EDC due to concern that moves towards a European army would compromise national sovereignty. Had the Six been committed to the EPC's membership norms, they could have retained them in some institutional form. Instead, they abandoned the EPC in favour of a liberal vision of European integration focused on eliminating barriers to trade. A committee of senior German civil servants and scholars appointed by German Economic Minister Ludwig Erhard had called in June 1953 for the creation of a European common market characterized by the free movement of labour, goods and capital, a single currency, and common regulatory legislation. ${ }^{1}$ As Erhard (1963: 155-158) saw it, the failure of the EPC's 'mechanically calculated formula' constituted an opportunity to pursue his vision of economic liberalization of the entire 'free world', starting with the convertibility of currencies. The influential Benelux Memorandum of 1955 followed the same vision, proposing that the ECSC member states adopt a general common market without national customs duties or import quotas. Jean Monnet (1955: 62) described the attitude of the Six at that point: 'Our Community is neither a small Europe nor a limited Community. Its limits are not set by us. They are set by those countries themselves who, for the moment, do not join it.'

This tension between two competing visions of European integration and their respective membership norms was soon resolved, however, by serious external challenges. The Soviet Union's threat to use force to repress political liberalization in Poland in August 1956 and the Red Army's invasion and crushing of an anti-communist uprising in Hungary three months later, revived fears of a communist threat to democracy throughout Western Europe. Meanwhile, the United States' insistence that Britain and France relinquish their military gains in the Suez crisis, and those two countries' inability to counter the Soviet invasion of Hungary, clearly demonstrated the limited power of West 
European states in this period. These developments bolstered support for a community membership norm that would exclude communist states while keeping the door open to all non-communist states, including some that would have been excluded by the democracies-only norm.

In April 1956, less than a year after formal talks between the foreign ministers of the six ECSC states began at Messina, the Intergovernmental Conference on European Integration proposed the creation of a European economic community focused on the free movement of labour and capital (Unspecified, 1956). The conference's first draft of a treaty, prepared soon thereafter, made no mention of membership criteria. Instead, it argued that it was 'necessary to pursue the establishment of a Europe united by the progressive fusion of national economies, the creation of a large common market and the progressive harmonisation of their social legislation'. ${ }^{2}$ As in the Treaty of Paris, no mention was made of limiting membership to states that ensure democracy or human rights.

This was not because the negotiators were unaware of alternatives: the conference chair, Paul-Henri Spaak, had also chaired the ad hoc assembly that drafted the EPC statute in 1953. This awareness is clearly reflected in a 1957 working paper of the intergovernmental conference, which explicitly compared the proposed membership clause of the new treaty to those included in the earlier ECSC, EDC and EPC treaties - the last of which would have limited membership to 'member states of the Council of Europe and all other European states that guarantee the maintenance of human rights and fundamental liberties'. ${ }^{3}$ Despite this side-by-side comparison, and the fact that adding EPC-like membership criteria would not have prevented any of the Six from joining the common market, the negotiators and the governments they represented chose not to limit the potential scope of the new community in this manner. The Six simply did not share the membership norms that had come closest to realization in the EPC treaty and did not want their membership choices to be constrained by such stringent criteria.

The Treaty of Rome's preamble does express the signatories' commitment 'to preserve and strengthen peace and liberty', but evidence from the negotiating record shows that the reference to liberty was understood principally in economic rather than political terms. ${ }^{4}$ The consistent focus on economic integration and the understanding of 'free world' prevailing in this period suggest that the negotiators understood 'liberty' as a reference to free markets and trade within the common market. Even 15 years later, when membership norms had clearly changed, Hallstein (1972) continued to define the Treaty of Rome's conception of 'freedom' as a commitment to the free movement of goods, services and workers, the free establishment of businesses, and free market dynamics regarding the production and consumption of goods.

In the end, the treaty provision on membership (Article 237) read simply:

Any European state may apply to become a member of the Community. It shall address its application to the Council, which shall act unanimously after obtaining the opinion of the Commission. The conditions of admission and the adjustments to the Treaty necessitated thereby shall be the subject of an agreement between the Member States and the applicant State. This agreement shall be submitted for ratification by all the Contracting States in accordance with their respective constitutional requirements. 
The treaty also included a provision (Article 238) allowing the EEC to sign association agreements with other states or international organisations. While Article 238 did not specify the possible purposes of association agreements or indicate any formal criteria for which states would be eligible, it was apparently drafted to facilitate close ties with European states outside the EEC and with other states (especially former colonies) with which the Six had long maintained close relations. At the signing of the Treaty of Rome, the Six adopted Declarations of Intent to conclude associations with Morocco, Tunisia, Libya, Italian Somalia, Surinam and The Netherlands Antilles, and many other states applied for EEC association in the years that followed (Phinnemore, 1999: 22). However, as with regard to membership, the treaty indicates that the Six preferred that their choices on association not be constrained by formal criteria.

The point of these observations is not that the governments that signed the Treaty of Rome cared little about democracy or human rights. However, the absence of democracy and human rights from the treaty that is widely celebrated as the source of today's EU was clearly no accident. Respect for these values had already been stipulated as strict criteria for membership in the Council of Europe and the aborted EPC, and they could have been added to the Treaty of Rome without changing the function, structure or initial membership of the new community. The constitutions of the six participating states were clearly based on democratic principles and all six were committed to the Council of Europe and its European Convention of Human Rights and Fundamental Freedoms. Thus, we are led inescapably to the conclusion that the founders of the EEC made a conscious choice in 1956-1957 (collectively if not individually) not to include democracy or respect for human rights as criteria for membership in their new community. Instead, motivated both by the liberal economic thinking that underlay planning for the common market and by the heightened geopolitical pressures of the Cold War, the EEC would be open to all non-communist states in Europe.

Within months of the Treaty of Rome's entry into force on 1 January 1958, the EEC's six governments and the European Commission had confirmed their commitment to the openness of the new community with the exception of communist states. This first became apparent in deliberations on the question of relations with the 11 non-EEC members of the Organisation for European Economic Cooperation (OEEC) - Austria, Denmark, Greece, Iceland, Ireland, Norway, Portugal, Sweden, Switzerland, Turkey and the UK. For example, the Commission's 'First Memorandum', drafted in close consultation with the governments of the Six in early 1959, recommended that any of the Eleven willing to pursue deeper integration should be offered association or full membership in the EEC in accordance with Articles 238 and 237 of the Treaty of Rome (Commission of the European Economic Community, 1959). Spain was not mentioned in any of these documents because it was not yet a member of the OEEC, but the casual inclusion of Portugal, a highly repressive dictatorship formerly allied with Nazi Germany, confirms that the presence or absence of democracy was not an important consideration.

Looking beyond the Eleven, though, EEC officials made no secret of their understanding that the new community would be closed to communist states. Robert Marjolin, Vice President of the European Commission and former head of the French delegation in negotiations on the Treaty of Rome, made this point unequivocally in a speech in Washington DC in April 1958. The creation of the EEC, he said, was: 
taken in a spirit of friendly cooperation with the other European nations in the hope that the union of the Six may in time become a broader union of free nations. ... We are determined to build a United Europe because we believe in the Free World and that the Free World will be stronger if we are stronger. (Marjolin, 1958)

Fifteen years after the treaty, Hallstein (1972: 19-20) recalled: 'the Europe that was about to unite belonged fully to the non-Communist world'.

These ideas were widely shared by the governments of the Six. In a crucial meeting of the EEC's Council of Ministers held in early 1960 to discuss how to respond to recent requests for association and membership, Belgian Foreign Minister Pierre Wigny interpreted the treaty as requiring simply that candidates for full membership must be European and must be capable of adjusting to the common external tariff and the absence of internal tariffs. France's Maurice Couve de Murville introduced the possibility of association agreements with a number of countries, including Spain (then still under fascist rule), and spoke of the 'great value' that he attached to 'the idea that the Common Market must give the impression of being an open association'. Germany's Heinrich von Brentano agreed that the common market 'must remain open', and warned that a failure to welcome Greece and Turkey could increase Soviet influence over those countries (Ministère des Affaires étrangères, 1996: document 35). Similarly, a lengthy study of the implications of the Treaty of Rome for EEC association and membership prepared by the Belgian Foreign Ministry in the winter of 1962 also makes no mention of democracy or human rights as possible criteria. ${ }^{5}$

\section{A Europe of non-communist parliamentary democracies, 1962-1969}

The Treaty of Rome was not amended in the 1960s, nor did the member states collectively issue any new authoritative criteria for EEC membership during these years. Yet, despite this continuity in formal rules, prevailing norms regarding the political requirements for membership changed significantly early in the decade. This normative change resulted in large part from political entrepreneurship by members of the European Parliamentary Assembly (EPA) frustrated by the absence of democratic principles in the Treaty of Rome. Many of them had earlier belonged to the parliamentary assembly of the Council of Europe, which was only open to democracies, or the ECSC Common Assembly, which had drafted the statute of the EPC. Despite the failure of plans for the EPC, these parliamentarians were strongly committed to the federalist vision of strong supranational institutions requiring and guaranteeing democracy and human rights at the national level. As shown later, their success in changing EEC membership norms depended upon two factors: a temporary dissensus among the Six; and the parliamentarians' ability to frame their demands with reference to national constitutional and Council of Europe norms.

Unhappy with the EEC's quasi-supranational method of decision-making and concerned that eventual British entry would further diminish French influence, Charles de Gaulle had proposed in 1960 that the Six establish an intergovernmental body to coordinate political, economic, defence and cultural policy. Although the other five member states were sceptical of De Gaulle's idea, which they feared would subordinate the EEC's 
new institutions to intergovernmental control and weaken the transatlantic alliance by creating a rival to the North Atlantic Treaty Organization (NATO), they agreed in February 1961 to explore the possibility of a political union among the members of the EEC and to open to subsequent enlargement. An intergovernmental committee chaired by French diplomat Christian Fouchet was charged with negotiating the details of such a union, but a lack of consensus among the Six was evident as soon as the committee began its work. The Dutch were particularly outspoken in support of the existing EEC institutions, the priority of NATO on defence cooperation and the importance of remaining open to British membership (Camps, 1964; Vanke, 2001).

In response, EPA members began to press their own vision, demanding that political union must not compromise the EEC's supranational institutions and insisting that they should not be open to all non-communist states. In the early autumn of 1961, the EPA's political commission appointed German social democrat Willi Birkelbach as chair of a working group on political and institutional aspects of the association and adhesion process. A former political prisoner of the Nazis, Birkelbach believed that the purpose of European integration was to advance democratic values and human rights:

We had seen how fragile democracy really was. We had seen it destroyed in our own country. ... The parliament's purpose was to ensure that the political, democratic nature of the Community was secure. It was important to show the Commission and the ministers that they had to give priority to democratic principles and institutions.

Birkelbach knew that if it were to overcome resistance from the EEC's member states, any re-conceptualization of the community's membership norms would have to be plausibly grounded in the Treaty of Rome, which declared '[a]ny European state' eligible to join. ${ }^{6}$

Fortunately for Birkelbach, De Gaulle's proposal for political union had reopened debate among the member states. On 2 November 1961, after months of committee deliberation and mutual concessions, Christian Fouchet distributed to his colleagues the first complete draft of a treaty on political union. The draft immediately encountered stiff resistance because of its inclusion of defence cooperation and the lack of clear openness to British participation, among other points. However, a significant element of the draft that does not appear to have sparked debate was its proposal that the union would be committed, inter alia, to 'the defense of human rights, fundamental liberties and democracy and to justice in every sphere of social life' and therefore that membership would be limited to states that already belonged to the EEC and the Council of Europe, the latter of which was only open to rights-protective democracies. These provisions directly echoed the 1953 draft statute for an EPC, which had been abandoned by the Six but retained as a goal by federalist parliamentarians.

Their inclusion in the draft treaty indicates that the EPA's agenda on membership eligibility was shared at least by some of the governments represented on the Fouchet committee. If formally adopted in a treaty on political union, these provisions would have constituted a major step beyond the Treaty of Rome's ambiguous commitment to 'liberty', its provision that 'any European state may apply to join' and the non-communist membership norm that prevailed in the EEC's early years. The problem was that 
such a membership norm would contradict the demonstrated policy preferences of at least two of the member states, France and Germany.

At the same time that the Six were debating the terms of political union, Birkelbach and his colleagues on the EPA's political committee were drafting their own report. Given the high profile of the Fouchet committee and its regular contact with the EPA's political committee, Birkelbach and colleagues would have been fully aware that the Six were now willing to consider the possibility that European integration should not be open to 'all European states' or even to any non-communist European state. Such ideas were not new — they had featured in the 1944 anti-fascist Ventotene Manifesto, the 1948 Statute of the Council of Europe and the unsuccessful 1953 draft Statute of the EPC but they had been rejected by the founders of the ECSC/EEC, much to the dismay of committed Euro-federalists like Birkelbach. Now, some of the Six had clearly proposed that membership in their community should only be open to European parliamentary democracies — a radical departure from the existing treaty and recently prevailing norms.

The question was whether a proposal made in the midst of inconclusive intergovernmental negotiations could be converted into a norm powerful enough to affect collective decision-making. While recognizing that Article 237's openness to '[a]ny European state' referred first of all to geography, Birkelbach and his EPA colleagues believed that the creation of a common market and the treaty's aspiration to 'ever closer union' implied other economic and political characteristics as well. Moving beyond the simple reference to 'liberty' in the treaty's preamble, the first draft of Birkelbach's report identified a 'democratic form of state' as a requirement for membership. During a meeting of the EPA political committee on 10 November, Commission President Walter Hallstein expressed his general approval of the draft, but a committee member voiced doubt about the definition of democracy (Assemblée Parlementaire Européenne, 1961).

On 19 December 1961, the political committee of the EPA unanimously adopted Birkelbach's report on association and adhesion, which asserted, despite the debate swirling around the Fouchet committee, that the political character of the community is 'no longer contested'. The opinion that the community is simply an 'enlarged international economic treaty' is almost never advanced, it says, except occasionally 'in those countries that begin to study more closely the bases of the three treaties in order to prepare their membership or association with the Community' (Assemblée Parlementaire Européenne, 1962). However, rather than tabling a federalist manifesto on moving beyond the Treaty of Rome, which was unlikely to gain broad reception, Birkelbach made sure to link the novel aspects of his text to political positions that were already accepted by political parties and governments of both the centre-right and centre-left.

Building upon the pre-existing norm that communist states were not eligible for membership, his report asserted that 'the political structure of [an applicant state] must not make it a foreign body in the Community'. Instead, the report proposed that any state applying for full membership must recognize and support the community's ultimate goal of political union, and must have domestic structures and foreign policies consistent with that goal. To start, it must support the general foreign policy commitments of the existing member states, that is, it must be willing and able to cooperate with the Western or Atlantic alliance. This principle would clearly exclude members of the Warsaw Pact, but 
the report did not take a position on whether it would also exclude neutral states such as Austria, Ireland, Sweden and Switzerland.

In addition, following the earlier query about defining democracy, the report offered a simple definition of which states were eligible for membership:

The guaranteed existence of a democratic form of state, in the sense of a free political order, is a condition for membership. States whose governments do not have democratic legitimacy and whose peoples do not participate in the decisions of the government, neither directly nor indirectly by freely-elected representatives, cannot expect to be admitted in the circle of peoples who form the European Communities.

On the other hand, the report was noticeably tentative on the question of whether respect for human rights should also be a formal requirement for community membership: 'One could ... suggest requiring of States that wish to join the Community that they recognize the principles that the Council of Europe has posed as a condition for those who want to be members of it.' Explanation of this clause is even relegated to a rare footnote: 'This involves above all recognition of the principles of the rule of law, human rights and fundamental freedoms (cf. article 3 of the Statute of the Council of Europe).'

The Birkelbach Report also addressed the question of association with the EEC, as provided by Article 238 of the Treaty of Rome. Some members of the political committee preferred to apply the same requirements to association and adhesion in order not to weaken the latter, but other members preferred a flexible stance on association. The final report thus recognized that association could take various forms, some more similar to membership and others more distant, and insisted simply that any association must be consistent with the 'fundamental political character of the Community'. Although it asserted that adhesion should be the general rule or expectation, and that association should be reserved for exceptional situations, it stopped short of establishing political criteria.

The Birkelbach Report did not impose new legal obligations on the community's members, nor did it reflect shared beliefs or policy preferences regarding enlargement among all the community's member states and supranational actors. However, its politically balanced provisions corresponded closely to the national constitutions of the Six, to proposals that they had accepted within the Fouchet committee and to their formal commitments within the Council of Europe, all of which made the report harder to refute or ignore than most emanations from the EPA, the weakest of the EEC's institutions. The release of the report in December 1961 and the reception that it received in early 1962 thus contributed to the emerging norm that the EEC was a community of parliamentary democracies within the Western alliance - a significant departure from the sparse content of the Treaty of Rome and from the membership norm that prevailed in the first half-decade after the treaty.

The fact that the report's assertions were novel for the EEC and contrary to the policy preferences of some of the member states' governments did not stop it from being recognized as an unassailable expression of the EEC's membership norm — variously praised and tolerated but never openly criticized at the European level. When Birkelbach presented his report to the full EPA on 23 January 1962, it was met with universal acclaim 
from members of various political groups within the assembly, as well as representatives of the European Commission. Socialist member Fernand Dehousse applauded the report's insistence that community membership was only open to states with similar economic and political structures, defining the latter in terms of parliamentary democracy and respect for human rights and fundamental freedoms for all. Christian democratic member Jean Duvieusart praised Birkelbach for looking beyond the geographic requirement for membership and defining economic and political criteria not articulated in the treaty: 'This document is more than a report ... it will constitute a foundational text, almost a law.' Duvieusart even predicted that the report would have an impact on European integration comparable to the 1955 Messina conference that led to the Treaty of Rome. Speaking for the European Commission, both Sicco Mansholt and Jean Rey welcomed the report as a valuable contribution to the development of a community 'doctrine' on association and adhesion (Assemblée Parlementaire Européenne, 1962). Such was the response to the report that Strasbourg's leading newspaper declared the following day that it could be considered "the "charter" for membership and association with the European Economic Community’ (Stock, 1962).

The strength of the emerging norm was also apparent when deliberations over political union resumed in early 1962 following a new proposal from the French government, reportedly drafted with personal input from Charles de Gaulle (Camps, 1964). It dropped the requirement that all members must also belong to the Council of Europe but retained the preambular affirmation of their collective 'attachment to the principles of democracy, of human rights, and of social justice'. Whether or not De Gaulle was informed about the Birkelbach Report, his aides surely were, and this revised draft treaty shows the French government's desire to fit their proposal to the emerging membership norm. France's five EEC partners immediately rejected the January draft, but their counter-proposal maintained the same preambular affirmation of democratic principles, as did a final draft treaty adopted by the Fouchet committee on 15 March (European Parliament, 1964). These negotiations on political union ultimately proved unsuccessful and the various draft treaties were abandoned, but the fact that all had included parliamentary democracy as a requirement for membership could only have reinforced the new norm.

The Council secretariat distributed the Birkelbach Report to the governments of the Six on 5 February 1962, even though they would have already been well acquainted with its contents. ${ }^{7}$ At about the same time, the Six asked the Commission to draft a comprehensive doctrine on association for their discussion. ${ }^{8}$ In an April 1962 speech, Commission vice-president for external relations Jean Rey lamented that the member states:

had not had the time ... to elaborate a doctrine regarding all these associations that rain down everywhere, to ask themselves what is to be done, which will be accepted, which will not be accepted, on the basis of which criteria.

Rather than focus on each application separately, Rey said, the community should address the general question, 'how does the Common Market conceive of its enlargement?' (Rey, 1962).

In mid-May 1962, Walter Hallstein informed the Council of Ministers of the Commission's full support for the Birkelbach Report — 'The Commission is of the 
opinion that if it had elaborated its own document on the subject [of association and adhesion] it would not have arrived at more valuable conclusions than those contained in the Birkelbach report' - and recommended that the Council take it as the basis for its own discussions. Hallstein then explained that the Commission did not believe that there existed, in the Birkelbach Report or elsewhere, any indisputable criteria that would automatically qualify an applicant state for association or adhesion; this required that the applicant state justify its demands to the community. In short, membership norms could disqualify an applicant state, but not ensure its acceptance. ${ }^{9}$ The following month, Hallstein (1962) gave an unreserved public welcome to the Birkelbach Report, declaring that its publication had 'enhanced the authority' of the EPA.

The report's close parallel to the national constitutions and Council of Europe commitments of the Six made it particularly difficult to rebut, even for member states troubled by its implications for their views on community enlargement. Neither the French nor the German government — both supportive of bringing Spain into the EEC and thus most likely to resist the report's recommendations - criticized the report publicly or even behind closed doors in EEC deliberations. Given that neither government had hesitated to criticize earlier assertions of authority by the EPA, this silence suggests that by early 1962, they accepted the Birkelbach Report as a legitimate (however inconvenient) expression of the community's new membership norm.

The persistence of the new norm alongside divergent member state preferences was evident during discussions among the Six of a 1964 Italian Foreign Ministry memorandum on the future of the community and its relations with third countries, which declared:

The European construction presupposes a substantial similarity of political systems within the member states. Membership is therefore excluded both for countries whose international status prevents them from assuming the obligations deriving from a future implementation of political unity and for countries whose domestic political regime is founded on significantly different criteria than those that inspire the six member states. ${ }^{10}$

In Council discussions, Belgium, Luxembourg and the Netherlands endorsed the Italian memorandum, while France and Germany expressed scepticism about its practical implications. ${ }^{11}$ However, as one would expect in the presence of an idea that had acquired normative status, none of the member states questioned whether only parliamentary democracies were eligible for membership.

\section{A Europe of liberal democracies, 1970-2005}

The next significant change in the EEC's membership norms - the inclusion of respect for human rights as a necessity for all member states - emerged out of the community's 1967 decision to freeze Greece's existing association agreement pending a reversal of the military coup and return to constitutional rule. Although the utility of the freeze was highly contested in internal community deliberations, its public justification by some community actors between 1967 and 1974 suggested that the military regime's lack of respect for human rights and the rule of law were just as important as its suspension of parliamentary democracy. This discourse went well beyond the Birkelbach Report's 
hesitant mention of human rights and its reference to political criteria for association as 'a very delicate question to which one cannot respond in a summary fashion'. As a result, it took several years before it was translated into a general membership norm.

The first public expression of this normative shift came in the October 1970 'Davignon Report' on political cooperation by the foreign ministers of the Six, which redefined the community's 'fundamental aim': 'A united Europe should be based on a common heritage of respect for the liberty and rights of man and bring together democratic States with freely elected parliaments' (Bulletin of the European Communities, 1970). Then, in December 1973, following the accession of Denmark, Ireland and the UK, the foreign ministers of the Nine issued a joint 'Declaration on the European Identity', expressing their determination 'to defend the principles of representative democracy, the rule of law, social justice - which is the ultimate goal of economic progress - and of respect for human rights'. They also spelled out the implications of this commitment for the community's enlargement: 'The construction of a United Europe ... is open to other European nations who share the same ideals and objectives' (Press and Information Office, 1988). With these two declarations, the member states identified themselves collectively for the first time as a community of liberal democracies founded on respect for human rights.

Step by step over the next two decades, EU member states and institutions reaffirmed and elaborated the new membership norm. In April 1977, the European Parliament, the Council and the Commission issued an unusual joint declaration affirming 'the prime importance they attach to the protection of fundamental rights, as derived in particular from the constitutions of the Member States and the European Convention for the Protection of Human Rights and Fundamental Freedoms' and committing to respect these rights in 'the exercise of their powers and in pursuance of the aims of the European Communities' (Official Journal of the European Communities, 1977). In 1978, the European Council's heads of state and government agreed a 'Declaration on Democracy' reaffirming the same principles as the 1973 declaration and reiterating that 'respect for and maintenance of representative democracy and human rights in each Member State are essential elements of membership of the European Communities' (European Council, 1978). In its 1978 submission to the European Court of Justice's Matheus v. Doego case, the Commission expressed its (new) interpretation of the EEC Treaty's Article 237:

It permits the accession of the state only if that state is a European State and its constitution guarantees, on the one hand, the existence and continuance of a pluralistic democracy and, on the other hand, effective protection of human rights. (Kochenov, 2004: 4)

In this new normative environment, it did not seem to matter that the EEC Treaty's text did not mention democracy or human rights.

As such, the 1993 'Copenhagen criteria' — 'Membership requires that the candidate country has achieved stability of institutions guaranteeing democracy, the rule of law, human rights and respect for and protection of minorities, the existence of a functioning market economy as well as the capacity to cope with competitive pressure and market forces within the Union' - are far less groundbreaking than is generally assumed. Similarly, the 1997 Amsterdam Treaty's unambiguous declaration that 'The Union is founded on the principles of liberty, democracy, respect for human rights and fundamental 
freedoms and the rule of law ... which are common to the Member States', is less a case of legal innovation than a move to bring the Treaty into line with a membership norm that had acquired taken-for-granted status by the late 1970s.

No critical voices were heard when the European Council declared at Laeken in 2001 that 'The European Union's one boundary is democracy and human rights. The Union is open only to countries which uphold basic values such as free elections, respect for minorities and respect for the rule of law.' In retrospect, though, the consensus among EU governments that only European states committed to the principles of liberal democracy were eligible for membership - and that all such states plausibly fulfilling this standard had a right to membership — peaked not long after Laeken.

\section{An uncertain Europe, post-2005}

New conceptions of the limits of Europe as a political community began to emerge in the early years of the new century, leading to a breakdown in normative consensus at the highest levels of the EU. One challenge to the pre-existing norms came from those who believed that the 'big bang' accession of 10 (and soon to be 12) new member states had stretched the finances and decision-making capacity of the EU to such an extent that it might never achieve its internal and external goals. Another challenge came from the belief that European integration requires an underlying cultural homogeneity that was being endangered by enlargement. This belief was linked to popular concern about the increasing power of European institutions, the growing number of immigrants (especially Muslims) across Europe in this period and Turkey's accelerated campaign for accession, which far-right and centre-right politicians were quick to exploit.

During the early 2000s, Austria's Wolfgang Schüssel was the only EU leader to question the EU's membership norm by arguing that Turkey was ineligible for accession because of its religious/cultural heritage. However, after the election victory of Angela Merkel in 2005 and then Nicolas Sarkozy in 2006, a significant bloc of member states were ruled by politicians who did not hide their scepticism about multiculturalism or their readiness to include cultural similarity as a requirement for EU accession. On the other hand, many member states' governments remained committed to the vision of the EU as a community of liberal democracies. For example, Swedish Foreign Minister Carl Bildt (2006) criticized:

those who want to slow down or perhaps even stop the process [of enlargement] altogether. There is talk of defining the borders of Europe. Drawing big lines on big maps of the east of Europe risks becoming a dangerous process.

As one would expect in a situation where membership norms had broken down and not been replaced by a new consensus definition of what types of states are eligible to join, EU discourse and deliberations on questions of membership since 2006 have been characterized by contention, hard bargaining and finally political deadlock on all but the easiest cases. Almost immediately after Merkel took power, the European Commission and European Parliament shifted their discursive focus to the EU's 'absorption capacity'. With Austria holding the EU presidency in the spring of 2006, Schüssel declared openly 
that membership eligibility involved a cultural component (Unspecified, 2006). French President Jacques Chirac explained that absorption capacity was partly about responding to popular anxieties about enlargement, so there must be a means for the citizens of member states 'to be able to say if they accept [the candidate state] or not' (Unspecified, 2006). Such comments led one journalist to conclude, 'the west European centre right has come up with an inelegant euphemism for Europe's borders: "absorption capacity", (Traynor, 2006).

Although the 2009 Lisbon Treaty reiterated that any European state committed to 'the values of respect for human dignity, freedom, democracy, equality, the rule of law and respect for human rights, including the rights of persons belonging to minorities', may apply for EU membership, it was clear by this point that the Treaty's formal commitment was not backed by a normative consensus among the community's member states and supranational institutions. When Jean-Claude Juncker became the new president of the European Commission in 2014, he made clear that further enlargement was not on the agenda of his presidency. Although no candidate country was likely to be ready for accession during this period, the move was also seen to be motivated by the breakdown in consensus among the member states (Unspecified, 2014).

\section{Conclusions}

The ultimate geographic limits of a regional community of states are defined by the membership norms that prevail within its member states' governments and its international institutions. These norms are a key indicator of how the community imagines itself politically and thus of which non-member states are likely to be invited to join. However, these membership norms are neither static nor internally determined: they are the subject of intense political contestation involving distinct visions of the community's political purpose, generally catalysed by encounters with non-members.

In Europe since the 1950s, state and non-state actors with divergent institutional preferences have repeatedly contested and transformed the normative definition of the European political community. The resulting norms have been translated - sometimes after considerable delay — into formal (treaty-based) rules designed to guide EU decision-making on enlargement regardless of the current preferences of the member states. It is nonetheless noteworthy that neither the content nor the timing of change in EU membership norms correlates with the evolution of the EU's formal membership rules. In fact, over the last decade, there has been an unprecedented breakdown in normative consensus within the community and thus a growing gap between the community's membership rules, which are slow to change, and the actual membership norms that prevail among the community's decision-makers.

Furthermore, and contrary to claims that today's EU treaties or the famous 'Copenhagen criteria' express enduring European values, we have seen that the EU's membership norms have sometimes had little to do with democratic institutions or respect for human rights. As such, a great deal of ahistorical commentary on the EU's normative 'identity' (e.g. Manners, 2002: 241-243) needs to be re-examined. The lesson here is clear: those who seek to understand the dynamics of regional integration, including a regional community's enlargement and external relations, should pay less attention 
to the content of treaties and more attention to the changing normative expectations of the member states' governments and senior figures in the community's institutions.

So, what does this mean for the future of European integration? At present, there is for the first time no consensus among the EU's member states and supranational institutions on how the community should assess the membership eligibility of applicant states. Furthermore, looking forward, it remains to be seen whether the EU's member states and supranational institutions will re-converge around a new shared definition of what makes a state eligible for membership. In the meantime, states seeking to join the club will have to manoeuvre between the formal definition of membership eligibility found in the Treaty on European Union and the political uncertainty caused by a lack of agreement among the member states. As long as this continues, EU decision-making on enlargement will remain highly contentious.

Looking further afield, there is good reason to expect that the membership norm dynamics evident in Europe are also present in other regions. Although regional communities in Africa, the Americas, the Middle East or Asia have different histories and institutional forms, all have member states with particular expectations regarding the characteristics that distinguish them from non-members. The internal dynamics of those regional communities, as well as their relations with outsiders, will be shaped by whether and how those expectations converge. This article's focus on the sources and evolution of membership norms thus offers a promising scholarly agenda for the growing field of comparative regional organization. Future studies should explore how and under what conditions membership norms shape regional organizations' decision-making in response to non-member states seeking accession and member states' governments whose behaviour challenges the prevailing norm.

\section{Acknowledgements}

The author wishes to thank Diana Panke, Bahar Rumelili, Jennifer Todd and the journal's anonymous reviewers for their helpful comments on earlier drafts of this article.

\section{Funding}

This research received no specific grant from any funding agency in the public, commercial or not-for-profit sectors.

\section{Notes}

1. Archives Diplomatiques, Ministère des affaires étrangères (Paris) (MAEF), Europe: Généralités (1949-1955), dossier 78: Lettre de l'Ambassadeur de France en Allemagne, 9 septembre 1953.

2. Historical Archives of the European Union (Florence) (HAEU), file HAEU CM3-NEGO-99 and file CM3-NEGO-100.

3. HAEU, file CM3-NEGO-262: Les clauses d'adhésion, 24 février 1957, MAE 643 f/57.

4. HAEU, file CM3-NEGO-182: Projet de rédaction du préambule, 14 janvier 1957, MAE 112 $\mathrm{f} / 57$.

5. Archives Diplomatiques, Ministère des affaires étrangères (Brussels) (MAEB), file 6641/1-s: Note sur les régimes d'adhésion et d'association prévus par le Traité instituant la Communauté Economique Européenne, 7 février 1962. 
6. Author's interview with Willi Birkelbach, Frankfurt, 15 July 2001.

7. Archives Historiques du Conseil de l'Union Européenne (Brussels) (AHCUE), file CM2.1.1962.

8. AHCUE, file CM2.848.1965.

9. AHCUE, file CM2.848.1964.

10. AHCUE, file CM2.848.1965.

11. AHCUE, file CM2.848.1965.

\section{References}

Abbott KW and Snidal D (1998) Why States Act Through Formal International Organizations. Journal of Conflict Resolution 42(1): 3-32.

Acharya A (2011) The Making of Southeast Asia: International Relations of a Region. Ithaca, NY: Cornell University Press.

Agence France-Presse (2006) Les négociations d'adhésion UE-Turquie pourraient être en danger. 29 June. Available at: http://www.info-turk.be/334.htm\#Relations (accessed 1 February 2016).

Assemblée Parlementaire Européenne (1961) Commission Politique. Proces-Verbal de la reunion du 10 novembre 1961, APE/I/PV/61-11.

Assemblée Parlementaire Européenne (1962) Débats, Session 1961-1962, Séances du 22 au 25 janvier 1962. APE/IV/62/No.52. Available at: http://aei.pitt.edu/44440/1/A6480.pdf (accessed 1 February 2016).

Bildt C (2006) Open wide Europe's doors. International Herald Tribune, 7 November.

Boyd A and Boyd F (1950) European Movement and the Council of Europe. London: Hutchinson $\&$ Co.

Bulletin of the European Communities (1970) Report by the foreign ministers of the member states on the problems of political unification. Adopted by the foreign ministers, Luxembourg, 27 October 1970, No. 11, pp. 9-14. Available at: http://aei.pitt.edu/4543/ (accessed 1 February 2016).

Camps M (1964) The Six and Political Union. The World Today 20(11): 473-80.

Cederman L-E (ed.) (2001) Constructing Europe's Identity: The External Dimension. Boulder, CO: Lynne Rienner Publishers.

Checkel JT (2005) International institutions and socialization in Europe: Introduction and framework. International Organization 59(4): 801-826.

Checkel JT and Katzenstein PJ (2009) European Identity. Cambridge: Cambridge University Press.

Commission of the European Economic Community (1959) First memorandum from the Commission of the European Economic Community to the Council of Ministers of the Community. 26 February. Available at: http://aei.pitt.edu/933/ (accessed 1 February 2016).

Constitutional Committee (1953a) Draft treaty embodying the statute of the European Community. Information and official documents of the Constitutional Committee, October 1952-April 1953. Available at: http://aei.pitt.edu/991/ (accessed 1 February 2016).

Constitutional Committee (1953b) Ad hoc assembly instructed to work out a draft treaty setting up a European Political Community, session of January 1953. Report of the Constitutional Committee. Paris, 20 December 1952. Available at: http://aei.pitt.edu/33690/ (accessed 1 February 2016).

Crowley U (2009) Genealogy method. In: Kitchin R and Thrift N (eds) International Encyclopedia of Human Geography. Amsterdam: Elsevier, pp. 341-344. 
De Menthon F (1948) Projet de Constitution fédérale des Etats-Unis d'Europe. June. Available at: http://www.cvce.eu/obj/projet_de_constitution_federale_des_etats_unis_d_europe_de_francois_ de_menthon_juin_1948-fr-ede91831-efb7-4cc9-b801-977654a7e60f.html (accessed 1 February 2016).

Erhard L (1963) The Economics of Success. Princeton, NJ: Van Nostrand.

European Council (1978) Documents from the European Council, Copenhagen, 7-8 April. Available at: http://aei.pitt.edu/1440/1/Copenhagen_1978.pdf (accessed 1 February 2016).

European Parliament (1964) Towards political union. A selection of documents with a foreword by Mr. Emilio Battista. European Parliament, Political Committee, January. Available at: http://aei.pitt.edu/944/ (accessed 1 February 2016).

Finnemore M and Sikkink K (1998) International norm dynamics and political change. International Organization 52(4): 897-917.

Giscard d'Estaing V (2000) Europe, Austria and Turkey. New Perspectives Quarterly 17(2): 18 20.

Hallstein W (1962) The European Economic Community as an element in a new world order. Address to the Diplomatic Press Association, Paris, 22 June. Available at: http://aei.pitt. edu/14825/ (accessed 1 February 2016).

Hallstein W (1972) The Making of Europe. London: George Allen \& Unwin.

Hemmer C and Katzenstein PJ (2002) Why is there no NATO in Asia? Collective identity, regionalism, and the origins of multilateralism. International Organization 56(3): 576-607.

Herrmann RK Risse T and Brewer MB. (eds) (2004) Transnational Identities: Becoming European in the EU. Lanham, MD: Rowman \& Littlefield.

Hurrell A (2005) Power, institutions, and the production of inequality. In: Barnett M and Duvall R (eds) Power in Global Governance. Cambridge: Cambridge University Press.

Klotz A and Prakash D (2009) Qualitative Methods in International Relations. Houndmills: Palgrave Macmillan.

Kochenov D (2004) Behind the Copenhagen façade: The meaning and structure of the Copenhagen political criterion of democracy and the rule of law. European Integration online Papers 8(10). Available at: http://eif.univie.ac.at/EIoP_Archive/pdf/2004-010.pdf (accessed 1 February 2016).

Krasner S (1988) Sovereignty: An institutional perspective. Comparative Political Studies 21(1): 66-94.

Kupchan CA (2010) How Enemies Become Friends: The Sources of Stable Peace. Princeton, NJ: Princeton University Press.

Manners I (2002) Normative power Europe: A contradiction in terms? Journal of Common Market Studies 40(2): 235-258.

Mansfield EL and Milner HV (1997) The Political Economy of Regionalism. New York, NY: Columbia University Press.

Marjolin R (1958) The free world's stake in the Common Market. Address to the International Press Institute and the American Society of Newspaper Editors, Washington DC, 17 April. Available at: http://aei.pitt.edu/14404/ (accessed 1 February 2016).

Ministère des Affaires étrangères (1996) Documents Diplomatiques Français 1960 Tome 1 (1 janvier-30 juin). Paris.

Monnet J (1955) Les Etats-Unis d'Europe ont Commencé. Paris: Robert Laffont.

Neumann IB (1999) Uses of the Other: The 'East' in European Identity Formation. Manchester: Manchester University Press.

Nye JS (1971) Peace in Parts: Integration and Conflict in Regional Organization. Boston, MA: Little, Brown. 
Official Journal of the European Communities (1977) Joint declaration by the European Parliament, the Council and the Commission. 77/C 103/01, 27 April.

Payne RA (2001) Persuasion, frames and norm construction. European Journal of International Relations 7(1): 37-61.

Pevehouse JC (2000) Democracy from Above: Regional Organizations and Democratization. Cambridge: Cambridge University Press.

Phinnemore D (1999) Association: Stepping-Stone or Alternative to EU Membership? Sheffield: Sheffield Academic Press.

Pistone S (1993) Il ruolo di Altiero Spinelli nella genesi dell'art.38 della Comunità Europea di Difesa e del progetto di Comunità Politica Europea. In: Trausch G (ed.) The European Integration from the Schuman-Plan to the Treaties of Rome. Baden-Baden: Nomos Verlag, pp. 393-413.

Preda D (1992) From a defence community to a political community: The role of de Gasperi and Spinelli. In: Bosco A (ed.) The Federal Idea, Vol. II: The History of Federalism since 1945. London: Lothian Foundation Press, pp. 189-206.

Press and Information Office (1988) Document on the European identity published by the nine Foreign Ministers, Copenhagen, 14 December 1973. In: European Political Cooperation (5th edn). Bonn: Press and Information Office, Federal Republic of Germany. Available at: http:// aei.pitt.edu/4545/ (accessed 1 February 2016).

Rey J (1962) Conference prononcée en la salle Academique de l’Université de Liege, le 9 avril. Available at: http://aei.pitt.edu/14811 (accessed 1 February 2016).

Risse T (2010) A Community of Europeans? Transnational Identities and Public Spheres. Ithaca, NY: Cornell University Press.

Ruggie JG (1999) What makes the world hang together? Neo-utilitarianism and the social constructivist challenge. In: Katzenstein PJ Keohane RO and Krasner SD (eds) Exploration and Contestation in the Study of World Politics. Cambridge, MA: MIT Press.

Rumelili B (2004) Constructing identity and relating to difference: Understanding the EU's mode of differentiation. Review of International Studies 30(1): 27-47.

Said EW (1978) Orientalism. New York, NY: Vintage Books.

Schimmelfennig F (2001) The community trap: Liberal norms, rhetorical action, and the eastern enlargement of the European Union. International Organization 55(1): 47-80.

Severino RC (2006) Southeast Asia in Search of an ASEAN Community: Insights from the Former ASEAN Secretary-General. Singapore: ISAES Publishing.

Stirk P and Weigall D (eds) (1999) The Origins and Development of European Integration: A Reader and Commentary. London: Pinter.

Stock R (1962) Strasbourg: Passionnant Débat Politique au Parlement Européen. Les Dernières Nouvelles d'Alsace (Strasbourg), 24 January, p. 5.

Traynor I (2006) The EU's weary travellers. The Guardian, 4 April.

United States Government Printing Office (1977) Foreign Relations of the United States, 1950, Volume 3: Western Europe. Washington, DC: United States Government Printing Office.

Unspecified (1956) Unofficial translation of the 'Spaak Report'. Available at: http://aei.pitt.edu/ archive/00000995/01/Spaak_report.pdf (accessed 1 February 2016).

Unspecified (2006) EU cements 'absorption capacity' as the new stumbling block to enlargement. EurActiv.com, 16 June. Available at: http://www.euractiv.com/future-eu/eu-cementsabsorption-capacity-new-stumbling-block-enlargement/article-156179 (accessed 1 February 2016).

Unspecified (2014) Serbia grudgingly accepts Juncker's enlargement pause. EurActiv.com, 16 September. Available at: http://www.euractiv.com/sections/enlargement/serbia-grudginglyaccepts-junckers-enlargement-pause-308481 (accessed 1 February 2016). 
Vanke JW (2001) An Impossible Union: Dutch Objections to the Fouchet Plan, 1959-62. Cold War History 2(1): 95-112.

Wendt A (1992) Anarchy is what states make of it: The social construction of power politics. International Organization 46(2): 391-425.

Wiener A (2004) Contested compliance: Interventions on the normative structure of world politics. European Journal of International Relations 10(2): 189-234.

\section{Author biography}

Daniel C. Thomas is Professor of International Relations in the Institute of Political Science at Leiden University, The Netherlands. 